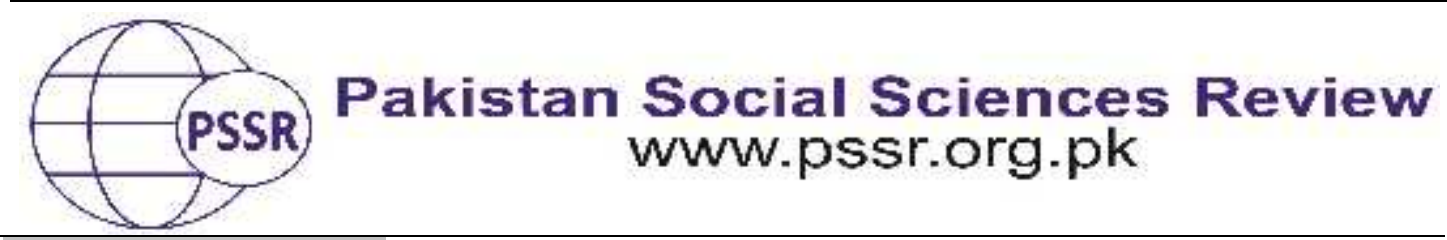

RESEARCH PAPER

\title{
Low Literacy Rate at Primary Level: Identification of Causes and Impacts
}

\author{
Mariam Javed $^{1}$ Dr. Qaisar Abbas* ${ }^{2}$ Dr. Shafqat Husssain ${ }^{3}$
}

1. M. Phil Scholar, Department of Education, Riphah International University Faisalabad Campus, Punjab, Pakistan.

2. Assistant Professor (Visiting), Department of Education, Riphah International University Campus Faisalabad, Punjab, Pakistan

3. Chairman, Department of Education, Government College University Faisalabad, Punjab, Pakistan

\begin{tabular}{|c|c|}
\hline PAPER INFO & ABSTRACT \\
\hline $\begin{array}{l}\text { Received: } \\
\text { February 13, } 2021 \\
\text { Accepted: } \\
\text { May 01, } 2021 \\
\text { Online: } \\
\text { May 15, } 2021\end{array}$ & $\begin{array}{l}\text { The current study was conducted to identify the causes of the } \\
\text { low literacy rate and its impact on the community at the } \\
\text { primary level. Two objectives were formulated (a) to explore } \\
\text { causes of low literacy rate and (b) to discover the impact of low } \\
\text { literacy rate on the community. All the teachers of primary }\end{array}$ \\
\hline $\begin{array}{l}\text { Keywords: } \\
\text { Community, } \\
\text { Identification, } \\
\text { Causes, } \\
\text { Low Literacy } \\
\text { Rate, } \\
\text { Primary Teachers }\end{array}$ & $\begin{array}{l}\text { schools working in the public sector and parents of the students } \\
\text { were the population. A sample of } 210 \text { ( } 200 \text { teachers and } 10 \\
\text { parents) was selected through the convenience sampling } \\
\text { method fromTehsil Kamaliadistrict Toba Tek Singh of the } \\
\text { Punjab province of Pakistan. An instrument based on a five- } \\
\text { point Likert scale for teachers and an interview schedule for } \\
\text { parents was used for data collection. Quantitative data revealed }\end{array}$ \\
\hline $\begin{array}{l}\text { *Corresponding } \\
\text { Author }\end{array}$ & $\begin{array}{l}\text { that overpopulation, lack of staff at schools, ineffective } \\
\text { curriculum, lack of discipline at schools, corporal punishment, } \\
\text { poverty, old teaching methods, social constraints/family } \\
\text { disputes, and health and safety were the causes of illiteracy. } \\
\text { Moreover, the study revealed that there had no political } \\
\text { influence on low literacy. Similarly, qualitative data also } \\
\text { confirmed that said indicators are the causes of low literacy. On } \\
\text { the basis of the results of the study, it is recommended that } \\
\text { government, as well as concerned authorities, should eradicate } \\
\text { said causes to improve the literacy rate. }\end{array}$ \\
\hline
\end{tabular}

\section{Introduction}

The importance of education in Islam is revealed in the first verse of the Holy Quran. In it, Allah commanded his beloved Prophet Muhammad (peace be upon him): "Read the name of Allah, who created the man of frozen blood. Lea, his teacher is the noblest knowledge, taught by the pen. He gave man such knowledge that he did not know" (Al-Alaq 1-5). Many verses from the Holy Quran shed light 
on the importance of education. In the Qur'an, Allah said: "Pray to God, Muhammad, and increase my knowledge." Similarly, in another place, Allah said: "The literate and the illiterate are not the same." Muhammad (peace be upon him) said: "It is the duty of every Muslim man and woman to acquire knowledge." (Abuarqub, 2009). There are many interesting links between literacy and Islam. Various verses from the Holy Quran shed light on the standing of education (Quora, 2015).

Keeping in view the importance of education, literacy empowers individuals to play their role in one's own and country development. It increases the youth with information of contemporary technology and makes areas for new creations as well as innovations. Currently, the literacy rate in Pakistan is low as $58 \%$ as compared to our neighboring countries like Iran $85 \%$, China $80 \%$, and India $74 \%$. The female literacy rate is worse as compared to males due to overarching patriarchal culture and challenging conditions for females (Ejaz, Afzal, \& Shurgeel, 2015). There are many factors that are responsible for the low literacy rate of Pakistan such as deficiency of staff, traditional curriculum, lack of discipline, poverty, traditional teaching methods, traditional government policies, low budget for education, inaccessibility of schools, teachers' absenteeism, favoritism in employment, lowquality jobs, overpopulation, poverty, lack of health system, a bad system of education etc. Presently, Pakistan is documented as the second-highest county out of school children with an estimation of 22.8 million children among the ages of 5 years to 16 years, with a representation of $44 \%$ of the whole population. Besides this, 5 million children aged from 5 to 9 years are not enrolled in school or receiving any formal education (Mtiaz, 2020 \& Nauman, 2020). According to Naeem (2013), Pakistan faces the challenge of a low level of literacy compared to developing countries.

The low literacy rate is of any country is considered an immense problem. In today's age, besides coronavirus, we are facing many crises, but the problem of low literacy is of the utmost importance. According to Plato, education means "the perfect development of man." Literacy, on the other hand, is considered an imperative step on the road to national progress. Education is such an optimistic lamp that the abilities mined by man get bright and internal lights, thus automatically eliminating the ways of darkness. Education is the cause of psychological, bodily, socioeconomic, dogmatic and psychical growth (Qureshi, 2003).

Illiteracy is considered a deficiency of reading, writing, and numeracy (3R). An illiterate person has many competitors, including contagion, hunger, disorder, and humiliation (Thengal, 2013). There are various reasons for the decrease in the literacy rate in various cultures such as overpopulation, shortage of teachers, corporal punishment, poverty, outdated curriculum, old teaching methods, illiterate parents, lack of family support, ancestral employment, little social contact with cities, and economic reasons. Transportation is not personal, it is social change (Durrani, 
2016). Low literacy rates affect the life of an individual and a community. Some of the consequences and consequences of the inability to read and write are: illiteracy, poverty, child marriage, difficult life, social crimes, unemployment, innate illiteracy, development of resources, and an impediment to social change, low dignity, and exclusion from entertainment, backwardness, and social backwardness (Victoria, 2019). The most common cause of illiteracy is our traditional culture based on pure agriculture and employment, in which education is not considered the basis of life. Farmers have been illiterate for centuries in the history of our social life. It was considered. If a child gets higher education, he will be useless on the farms. This means that the cultivation of the land and education are seen as opposing ideas in our agricultural society (Saqib\& Ahmad, 2015).

The Kamalia city is the 4th tehsil of district Toba Tek Singh of the Punjab province of Pakistan. It is documented as the $67 \mathrm{th}$ largest tehsil by population. The total population of this city is comprised of 3, 78,851 of which 236,211 are living in rural areas and 135,640 in urban areas (Pakistan Bureau of Statistics, 2017). The residents of Kamalia city are very famous for their courteously and friendship. Most of the people of this city are doing their own micro-scale businesses comprising vendors selling in bazaars, the farmers, the commission agents, and the workers of weaving units (looms). The main issue of Kamalia city is lack of education due to many factors such as lack of universities, colleges, schools, poverty, and financial resources for the children. Moreover, the most important factor is that the children from humble families' backgrounds have to run their family business instead of getting their education due to lack of finances for education (Miraj, 2013). Most of the people live in rural areas and are associated with agriculture. Some are farmers and some help the farmers. A student enrolled in a school is considered useless to them. In addition, they say that he will not get work in the offices and will not be able to cultivate the land, thus ruining his life(Naeem, 2013).

\section{Literature Review}

Many investigations were directed to explore the factors that contribute towards illiteracy worldwide. In the context of Pakistan, the study complete by Amir (2019) indicated in his research the causes of illiteracy such as slow economic growth, poverty, poor education system, and lack of good teaching skills in teachers. He further stated that most criminals are illiterate and they are unable to make differences between good and bad deeds due to their unawareness. Amir further told that violence in society is due to illiteracy. Tahira (2018) revealed that illiteracy occurs due to several factors such as poverty, financial issue, child marriage, and high growth rate of population. Her study also concluded that females' illiteracy is very high as compared to males. She further supported the women and suggest that females should not be restrained to their but has the right to get well education. Ahamd (2017) directed a study to explore and compare literacy rates among developing countries such as Pakistan, Afghanistan, and South Sudan. His investigation concluded that Pakistan's literacy is better as compared to said countries. Furthermore, he indicated that nine education policies that the Pakistani government has offered in the last seventy years with effect to resolve the issue of 
illiteracy. But, he further indicated that the issues exist because of broad policy hurdles and some other factors such as political will, low budget, and delay in the passing funds, corruption, and lack of teachers' training. Victoria (2019) found that poor low-income parents have difficulty paying school fees. They are forced to choose between providing basic necessities such as food, shelter, and clothing or taking their children to school. In countries where basic education is not free, the number of children who do not go to school is higher compared to places where basic education is free and compulsory.

Illiteracy greatly hinders the economic and social progress of a person and a country. Education allows one to seek and pursue opportunities. People who have been to school or have a good education have the skill and intelligence to make good investment decisions and advance a country's growth agenda. Hence, illiteracy hinders the development of the country (Saqib\& Ahmad, 2014). Literacy is an integral part of our lives. The results of low literacy are far-reaching and affect all areas of our daily lives. As people's needs change, so do the ways illiteracy affects people. Here's a sample of how low literacy affects us as individuals and as a community (Qureshi, 2013). Literacy affects income, employment, and financial wellbeing (Chaudhry et al., 2006). A variety of literacy skills are intertwined with basic and complex financial and decision-making tasks. Financial literacy requires the ability to use multiple kinds of literature at the same time: prose, documents, and numbers. For many, lack of literacy and lack of financial literacy makes it difficult for them and their families to lead better lives (Hussain \& Salfi, 2011). Most teachers saw themselves as responsible for dropping out of school due to corporal punishment and inattention to students. Given that literacy is an indispensable tool for individuals and states to compete in the new global knowledge economy, many positions are vacant due to a lack of properly trained staff to maintain them; Without the basic tools necessary to achieve the objectives, people who are not sufficiently literate cannot participate fully and equally in social and political discourse (Din et al., 2011). Moreover, the investigation of Kim et al., (2014) revealed that low literacy is a serious health and safety problem at home and in the workplace. From reading the dosages instructions on a medicine bottle to interpreting plans and instructions, understanding the signs and warnings of hazardous substances, to maps and diagram that follow the list. When there is a need for literacy in written language, numbers or diagrams, and symbols, adults with literacy problems are at risk; these risks can be life-threatening. Now it seems imperative to look into the context of illiteracy and its impact on the community.

\section{Research Questions}

On the basis of objectives, the below research questions were designed:-

1. What are the major causes of low literacy rate at primary level in Tehsil Kamalia?

2. What is the Impact of low literacy rate on community at Tehsil Kamalia 


\section{Material and Methods}

The researchers adopted a mixed-method triangulation research design. Triangulation is a very common approach to mixed-method (Creswell, Plano Clark et al., 2003) which involves the QUAN-QUAL model. In this model, the researchers collected quantitative data at the first stage and qualitative data at the second stage for collecting different but complementary data on the same topic to understand the problem under investigation. All the teachers working in government primary schools of Tehsil Kamalia and the parents were constituted as the population of this study. A sample of 200 primary teachers ( 92 male \& 102 female) and 10 parents (05 mothers \& 05 fathers) was selected through the convenience sampling method. Two researchers developed instruments were used. A five-point Likert scale questionnaire based on 20 items was used for the collection of teachers' views and an interview schedule was developed for the collection of parents' feelings about the phenomena under study. Instruments' validity and reliability were confirmed through experts and scale reliability test as $(a=0.78)$. Teachers' responses were analyzed by descriptive statistics and parents' interviews were analyzed by thematic analysis. The findings of the study were as under.

\section{Results and Discussion}

RQ1: What are the major causes of low literacy rate at primary level in Tehsil Kamalia

Table 1

Mean scores and SDs of Teachers' responses towards major causes of low literacy

\begin{tabular}{ccccc}
\hline $\begin{array}{c}\text { Sr } \\
\text { No. }\end{array}$ & $\begin{array}{c}\text { Indicators of causes of } \\
\text { Low Literacy }\end{array}$ & $\mathrm{N}$ & Mean & S.D \\
\hline 1 & Over-population & 200 & 3.56 & 1.126 \\
\hline 2 & Lack of staff & 200 & 3.79 & .998 \\
\hline 3 & Ineffective curriculum & 200 & 3.61 & 1.024 \\
\hline 4 & Lack of Discipline & 200 & 3.47 & 1.066 \\
\hline 5 & Corporal Punishment & 200 & 3.48 & 1.059 \\
\hline 6 & Economic status & 200 & 3.91 & .949 \\
\hline 7 & Old methods of teaching & 200 & 3.68 & .919 \\
\hline 8 & Political influence & 200 & 3.68 & 1.037 \\
\hline 9 & Social constraints & 200 & 3.87 & .932 \\
\hline 10 & Health and safety & 200 & 3.86 & .889 \\
\hline & Overall Mean Scores: & - & 3.69 & 0.999 \\
\hline
\end{tabular}

Table 1 demonstrates the teachers' perceptions towards the indicators of the causes of low literacy with a mean score about overpopulation $(\mathrm{M}=3.56, \mathrm{SD}=1.126)$, lack of staff $(\mathrm{M}=3.79, \mathrm{SD}=.998)$, ineffective curriculum $(\mathrm{M}=3.61, \mathrm{SD}=1.024)$, lack of discipline $(\mathrm{M}=3.47, \mathrm{SD}=1.066)$, corporal punishment $(\mathrm{M}=3.48, \mathrm{SD}=1.059)$, Economic Status $(\mathrm{M}=3.91, \mathrm{SD}=.949)$, Old methods of teaching $(\mathrm{M}=3.68, \mathrm{SD}=.919)$, Political influence $(\mathrm{M}=3.68, \mathrm{SD}=1.037)$, Social constraints $(\mathrm{M}=3.87, \mathrm{SD}=.932)$, and Health and 
safety $(3.86, \mathrm{SD}=.889)$. It is noticeable from the result of the overall mean score which above 3.0 out of 5.0 and favorable to all the indicators of causes of low literacy. These outcomes revealed that the majority of the primary teachers were agreed with all the indicators about the causes of low literacy at the primary level in Kamalia Tehsil of Punjab, Pakistan. These results were in line with the studies' results of Mtiaz, (2020), Amir (2019), and Tahira (2018) as they also discovered similar causes of illiteracy in their studies. The outcomes of this study were also in line with the study's results of Hussain and Salfi (2011). Moreover, the investigation of Kim et al., (2014) revealed that low literacy is a serious health and safety problem at home and in schools which is in line with the results of this study.

Table 2

Gender wise comparison about teachers' responses towards indicators of the causes of low literacy

\begin{tabular}{|c|c|c|c|c|c|c|c|}
\hline Indicators & Gender & $\mathbf{N}$ & Mean & Std. Deviation & t-value & df & p-value \\
\hline \multirow{2}{*}{ Over Population } & Male & 98 & 3.56 & 1.169 & \multirow{2}{*}{-.077} & \multirow{2}{*}{198} & \multirow{2}{*}{.939} \\
\hline & Female & 102 & 3.57 & 1.088 & & & \\
\hline \multirow{2}{*}{ Lack of Staff } & Male & 98 & 3.68 & 1.063 & \multirow{2}{*}{-1.478} & \multirow{2}{*}{198} & \multirow{2}{*}{.141} \\
\hline & Female & 102 & 3.89 & .926 & & & \\
\hline \multirow{2}{*}{$\begin{array}{l}\text { Ineffective } \\
\text { curriculum }\end{array}$} & Male & 98 & 3.61 & 1.069 & \multirow{2}{*}{-.002} & \multirow{2}{*}{198} & \multirow{2}{*}{.998} \\
\hline & Female & 102 & 3.61 & .985 & & & \\
\hline \multirow{2}{*}{ Lack of Discipline } & Male & 98 & 3.34 & 1.033 & \multirow{2}{*}{-1.672} & \multirow{2}{*}{198} & \multirow{2}{*}{.096} \\
\hline & Female & 102 & 3.59 & 1.087 & & & \\
\hline \multirow{2}{*}{$\begin{array}{c}\text { Corporal } \\
\text { Punishment }\end{array}$} & Male & 98 & 3.33 & 1.085 & \multirow{2}{*}{-1.921} & \multirow{2}{*}{198} & \multirow{2}{*}{.057} \\
\hline & Female & 102 & 3.62 & 1.018 & & & \\
\hline \multirow{2}{*}{ Economic status } & Male & 98 & 3.83 & .946 & \multirow{2}{*}{-1.218} & \multirow{2}{*}{198} & \multirow{2}{*}{.225} \\
\hline & Female & 102 & 3.99 & .950 & & & \\
\hline \multirow{2}{*}{$\begin{array}{l}\text { Old teaching } \\
\text { methods }\end{array}$} & Male & 98 & 3.64 & .885 & \multirow{2}{*}{-.597} & \multirow{2}{*}{198} & \multirow{2}{*}{.551} \\
\hline & Female & 102 & 3.72 & .953 & & & \\
\hline \multirow{2}{*}{ Political Influence } & Male & 98 & 3.59 & 1.119 & \multirow{2}{*}{-1.213} & \multirow{2}{*}{198} & \multirow{2}{*}{.227} \\
\hline & Female & 102 & 3.76 & .948 & & & \\
\hline \multirow{2}{*}{ Social Constraints } & Male & 98 & 3.82 & .847 & \multirow{2}{*}{-.758} & \multirow{2}{*}{198} & \\
\hline & Female & 102 & 3.92 & 1.009 & & & .449 \\
\hline & Male & 98 & 3.83 & .935 & & & \\
\hline Health \&safety & Female & 102 & 3.88 & .846 & -.44 & 198 & .660 \\
\hline
\end{tabular}

Table 2 illustrates the gender-wise comparison of their responses towards the causes of low literacy. Statistical outcomes revealed that there had an insignificant difference between the male teachers and female teachers. P-values of all indicators of causes of low literacy were above 0.05 , which confirmed that there had no difference between the responses of male and female teachers. These results revealed that teachers belonging to both genders were equally agreed towards all indicators of the causes of low literacy. 


\section{Analysis of Qualitative Data (Parents' Interviews)}

After interpretation of quantitative data, 10 parents (5 mothers \& 5 fathers) were selected and they were interviewed to confirm the results of quantitative data. The data collected during interviews were analyzed through thematic analysis. RF represents as father respondents\& RM represents as mother respondents.

Q.1. Do you believe that overpopulation is a big cause of low literacy?

\section{Theme 1: Over Population}

RF 1-5 voiced during interviews that they were agreed that overpopulation is a serious issue and cause of illiteracy. RF5 further expressed that overpopulation is increasing illiteracy in the community. RF1, RF2, and RF3 said that through educating parents overpopulation can be controlled. RF4 and RF5 expressed that we should focus on the education of our community to increase literacy. Similarly, RM1, RM2, RM4, and RM5 stated that rapid increase of population is the basic cause of low literacy, while RM3 said that unawareness of the people about benefits of education is the cause of illiteracy. Thus, qualitative data analysis revealed that the majority of the respondents were agreed that overpopulation is the cause of low literacy.

Q.2. Do you agree that a low literacy rate is due to a lack of staff at primary schools?

\section{Theme 2: Lack of Staff}

In response to this question, RF1, RF3, RF4, and RF5 stated that lack of staff is also a reason for low literacy. RF1 expressed that he had seen that in primary schools one teacher has deputed to control 2 to 3 classes due to deficiency of teachers. RF4 further voiced that teachers' training about how to deal with children should be compulsory before entering this profession. RF3 said that government should retire old teachers and the new generation should be appointed for proper teaching with innovation. RF1, RF2, RF4, and RF5 stated that government should fill the vacant posts immediately to increase the literacy level. On the other hand in response to this question, RM1, RM2, and RM5 stated that primary schools are facing a lack of staff and teachers are controlling the mixing of classes. So, they told that lack of staff is the reason for low literacy. RM3 said that due to huge strength our teachers are unable to focus on each child's learning and individual differences. RM4 replied that the lack of competent teachers is the cause of low literacy. All respondents suggested that government should fill the vacant posts by appointing competent teachers. Consequently, qualitative data revealed that most of the respondents were agreed that lack of staff is the cause of low literacy.

Q.3. Do you think that ineffective curriculum is a cause of low literacy? 


\section{Theme 3: Ineffective Curriculum}

During interviews, RF1 told that our curriculum is effective and fulfills the needs of students, but RF2, RF3, RF4, and RF5 expressed that our curriculum is ineffective and a cause of low literacy. RF2 further told that our curriculum is based on English which is not understandable to the children. RF3 said that the English curriculum unable to provide skills to our children. RF4 told that curriculum is the way in which any nation reaches its goals of development and progression. RF5 told us that our curriculum is not according to the interests of our children. Respondents suggested that the curriculum should be according to the interests of children. The curriculum should be in the Urdu language for a complete understanding of the children. The curriculum should be updated according to the demands of society. And new curriculum should be prepared considering the interest of the children. On other hand, RM1 said that our curriculum is good but there are heavy bags on the shoulders of little children. RM1 further replied that curriculum is not a reason for low literacy. RM2 said that if the curriculum is not interesting then the child will ignore it. RM3, RM4, and RM5 said that our curriculum is not effective. Respondents suggested that an effective curriculum should be provided to attract the children; otherwise the literacy rate will go more down. The curriculum should be based on activities of the concerned area of the school. So, that children show interest towards learning. On the basis of qualitative data analysis, it had revealed that an ineffective curriculum is the cause of low literacy.

Q.4. Do you think that discipline issues, at schools are increasing illiteracy?

\section{Theme 4: Discipline}

In response to this question, RF1, RF3, and RF5 agreed that somewhat of discipline is also a cause of low literacy. RF5 further told that it is the desire of parents that their children should be disciplined. But RF3 and RF4 disagreed with the expressions of RF1, RF3, and RF5. RF1 further stated that at school some teachers impose hard disciplinary rules on the students of unknown families which show that teachers practice favoritism at schools. RF4 voiced that there had no written rules for discipline at schools. All participants suggested that soft rules should be prepared with the collaboration of parents in written form to maintain discipline at school. Thus, the analysis revealed that most of the parents were agreed that discipline is the cause of low literacy. Similarly, RM1 indicated that most of the students leave the school due to less discipline at our schools, RM2 told that most children do not follow disciplinary rules and they are punished and become rebellious and leave the school, RM3 voiced that discipline develop "Tarbiyat" in students, but children of today have no "Tarbiyat". Out of five mothers, three were agreed that discipline is the cause of illiteracy. But RM4 said that discipline is not a cause of low literacy. Proper discipline maintained at our schools, and RM5 also voiced that strict discipline is not the cause of low literacy. Discipline develop students' personality. All the participants suggested that teachers should use soft disciplinary rules, effective disciplinary rules should be prepared, and a PTI should be appointed to 
maintain discipline at schools. Consequently, analysis exposed that most of the mothers were agreed that lack of discipline at schools is the cause of low literacy.

Q.5. Do you think that Corporal Punishment at schools is a cause of low literacy?

\section{Theme 5: Corporal Punishment}

In response to this question, RF1, RF2, RF3, RF4, and RF5 were agreed that due to the fear of corporal punishment children leave schools and it is a serious cause of low literacy. RF2 further voiced that there had a lack of tolerance in children. RF3 expressed his feelings that teachers use verbal and non-verbal punishment. RF4 told that there had less cooperation from teachers. RF1 suggested that government should train teachers to show deep love for children, RF2, RF3, RF4, and RF5 said that each type of corporal punishment should be banned which is the cause of low literacy. Therefore, analysis exposed that most of the fathers were agreed that verbal and non-verbal punishment is the cause of low literacy. Likewise, RM1, RM2, RM3, RM4, and RM5 were agreed that at schools some teacher gives punishment such as insulting students in front of others, teachers beat students, and teachers exhibit angry behavior to the students which develop fear in the students and they left the school. Thus, they suggested that teachers should avoid to practices such types of punishment which is the basic cause of low literacy. Therefore, analysis declared that most of the mothers were agreed that corporal punishment is the case of low literacy.

Q.6. Do you think that the Economic problem of parents is a cause of low literacy?

\section{Theme 6: Economic Problems}

In response to this question, all respondents expressed that economic problem is the major cause of illiteracy. RF1 told that most of the parents belong to poor families and they are unable to give pocket money to their kids daily. So, they like to attach their kids in their own labor work as helpers or deputed them at the various workshops as laborers. RF2 and RF3 told that parents prefer to send their children to shops, hotels, etc for earning as well as learning skills purposes. RF4 expressed that parents' economic status also influences children's psychological development and progress. RF5 voiced that the children of rich parents are taking their education in a reputed school system and they are progressing day by day. But on the other hand poor parents unable to face the expenses of their kids needed for education. So, the analysis revealed that all fathers were agreed that their economic problems are the causes of illiteracy. On the other hand, RM1 to RM5 were agreed that poverty is the cause of low literacy. RM1 said that most of the parents are unable to send their children due to poverty. RM2 stated that parents' income influences their children's education. They prefer to send their children to workshops for learning skills to earn money. RM3 told that poor parents' first priority is to provide food to their families instead of education. So, this is a big hurdle in illiteracy. Poor parents are unable to pay pocket money and face stationery expenses of their children. RM4 told that most of the parents are poor as well as un- 
educated in our community. So, these two reasons are the major cause of illiteracy. RM5 replied that due to poverty parents wish to carry their children with them at a job placement for their own help. Hence, the analysis discovered that all mothers were agreed that the economic problems of families are the causes of low literacy.

Q.7. Do you think that ineffective Methods of teaching is a cause of low literacy?

\section{Theme 7: Teaching Methods}

In response to this question, RF1 communicated that teachers did not use innovative methods of teaching, focus on individual differences due to huge strengths in class. RF2 expressed that the old teaching method is not interesting for students. The children of this era are more expert in digital devices, so teachers should recognize the caliber of the student and should use innovative methods to teach the children known as the next generation. RF4 voiced that the old teaching method should be changed. Teachers should use the discussion method to increase the confidence of the children. He further stated that old methods of teaching are also a reason for low literacy but in our schools' teachers is using only the lecture method which is not suitable for little children. RF5 said that I am agreed that if teachers taught children through effective methods of teaching then they will learn and understand eagerly. Only RF3 stated that teaching methods are good and there are no effects of teaching methods on low literacy. No need to change the teaching methods. Therefore, analysis exposed that most of the respondents were agreed that old teaching methods are the cause of low literacy. On the other hand, RM1 and RM2 stated that teachers are not using teaching methods according to students" interests. Children became bored. So, teachers should use those teaching methods in which children show their interest. She further described that old teaching methods have no value for today's children and it is also an issue of illiteracy. RM 3 told that due to huge strength in classes, teachers are unable to use new methods of teaching. So, the student-teacher ratio should be 20 children per teacher. RM5 told that teachers' teaching methods are not innovative. Teachers should adopt new methods of teaching. Only RM4 said that teachers' teaching methods are good and this is not the cause of low literacy at all. Thus, analysis expressed that most of the mothers were agreed that teachers use old teaching methods which is the cause of illiteracy.

Q.8. Do you think that Political Influence is a cause of low literacy?

\section{Theme 8: Political Influence}

In response to this question, RF1 to RF4 voiced that there had no political influence on illiteracy. RF2 further told that according to my own observation now there is less political influence in schools. RF4 said that there is no outside political influence on low literacy but politics inside schools among teachers is increasing day by day. It should be stopped and teachers should focus on their teaching to increase the literacy of our novel generation. Only RF5 said that there is a huge influence of politics on the education system. If the government makes a plan through political 
leaders for the proper education of all communities then the literacy rate will be increased. Thus, the analysis revealed that the majority of the fathers were agreed that there had no political influence on illiteracy. In response to this question, RM1, RM2, RM3, and RM4 said that political influence is not a cause of low literacy. RM4 further said that there is no political influence on low literacy at the primary level. But RM5 told that there is political influence on low literacy. It should be removed. Thus, the analysis concluded that the majority of the mother were agreed that there had no political influence on low literacy.

Q.9. Do you think Social Constraints (family disputes) are causes of low literacy?

\section{Theme 9: Social Constraints}

In response to this question, RF1 to RF5 all were agreed that social constraints (family disputes) are the cause of low literacy. RF1 further told that disputes affect a child' mentally and physically. Children are these families became psychological patients and unable to continue their studies due to illness. RF2 said that every family has many domestic issues and disputes which can affect their children's education. Parents should stay their children away from family issues or disputes for their proper growth mentally and emotionally. RF3 said that family' disputes create stress in the mind of the children. Consequently, children failed to focus on their studies at schools as well as at home. RF4 expressed that parents' own disputes seriously affect their children's psychological development. Children become mentally ill and failed to continue their education. So, parents should consider this issue and avoid practicing any dispute before children. RF5 voiced that when various disputes occurred in families, the children of that family lose their spirit towards education. So, children should be taught tolerance at school as well as at home to face these problems positively. In response to this question, RM1 to RM5 all were agreed that social constraints (family disputes) are the cause of low literacy. RM1 further stated that it is real fact that all families belonging to poor, middle, or upper status have many issues and disputes. When parents discuss these issues in front of little kids, they became aggressive and failed to focus towards study. This is a serious problem and I think parents should stop to practice or discuss any dispute in front of little kids. RM2 told that when parents quarrel at home than their children remember that scene always and become aggressive in future life. Their thinking about that scene unable them to focus towards studies. RM3 replied that this is true that children leave school due to various family problems. The family should manage these problems at their own end. RM4 voiced that due to family disputes children leave the school and became aggressive. RM5 that due to parents' quarreling behavior the studies of their children can be affected. Thus, the analysis exposed that all respondents were agreed that social constraints (family disputes) are the causes of low literacy.

Q.10. Do you think that Health and safety (Coronavirus situation) is increasing illiteracy? 


\section{Theme 10: Health and Safety}

In response to this question, RF1 to RF5 all were agreed that lack of health and safety including coronavirus pandemic is increasing illiteracy. RF1 further exposed that there were a lot of issues related to health and safety in schools. In Schools as well as in street shops there were a lot of kids' unhealthy eatable items which are affecting kids' health. Our government is failed to manage local street shops for the provision of healthy items for kids. So, health and safety are also a cause of low literacy. He also told that during the lockdown of coronavirus most of the parents sent their children to learn skills and to earn income. RF2 told that due to the coronavirus problems most of the students left the schools because of the closure of the schools. RF3 said that the illness of kids is also increasing low literacy. Government should provide complete health facilities for our children at our doorsteps.RF4 expressed that I have seen many children fighting with diseases but their parents unable to give them proper treatment. The Health and safety of the children is a very serious issue which is increasing illiteracy. Government should establish a dispensary at every school for the basic treatment of the child. RF5 further said that "Jaanhai to Jahaanhai". If the child is ill he or she unable to concentrate on education. So, Government should establish dispensaries at schools for their treatment to share the load of poor families. Thus, the analysis revealed that health and safety are the cause of illiteracy. Likewise, RM1 to RM5 were agreed that the health of the children is essential for the study. So, illness affects their education. RM1 further told that when children become ill, parents are unable to give better treatment to them due to poverty. In this way, the education of their children is affected. She further told that there should be a free annual health checkup system at schools to manage children's health properly. RM2 also voiced that health is the top priority of every parent. So, proper health facilities should be provided at schools to increase literacy. RM3 expressed that I have seen many poor children who took unhealthy food and become ill. Their parents are unable to give proper treatment and pay huge doctor's fees and medical expenses. So, the health of a child is also a serious issue in illiteracy. RM4 told that Government should provide free health facilities to all children. RM5. Government should develop a proper mechanism to control the wrong eatable items at schools' canteen and in market shops also. Consequently, the analysis revealed that students' health and safety are the cause of illiteracy.

Q.11. According to your point of view, what is the impact of illiteracy on community?

\section{Theme 11: Impact on Community}

In response to this question, the responses of fathers and mothers were as follows:-

RF1 to RF5 (Fathers) told that illiteracy produces less confidence in children, less social responsibility, low personal growth, high unemployment, increased overpopulation, increased poverty, slow economic growth, increases child marriage, 
increases un-awareness own rights and violence in the community. While, RM1 to RM5 (Mothers) voiced that low literacy contributes to the community in terms of inability in children, immoral activity, unawareness about own rights, and less participation in the community for positive activity. These results are in line with the study's results of Hussain and Salfi (2011) as they revealed the same effects of illiteracy on society like lack of literacy and lack of financial literacy makes it difficult for people and their families to lead better lives. The study's results of Chaudhry et al., (2006) revealed that illiteracy impact on the community in term of low-income, unemployment, violence, unawareness and financial well-being which are also supported the results of the current study.

\section{Conclusions}

Literacy is recognized as the vital element of every development of the individual, community, and country. Most of the nations have achieved a $100 \%$ literacy rate and ruling over the global economy. But, in Pakistan, the literacy rate is still unsatisfactory which is alarming for all stakeholders involved in the education system. Quantitative results confirmed that overpopulation, lack of staff, ineffective curriculum, lack of discipline, corporal punishment, poverty, traditional teaching methods, social constraints, and health and safety were the causes of low literacy. There had no significant difference between the opinions of male and female primary teachers regarding causes of low literacy. Moreover, qualitative data also proved that there were some causes of illiteracy instead of political influence.

\section{Suggestions for Future Research Work}

The investigation should be extended to other areas of Pakistan at primary, secondary, higher secondary level by involving all stakeholders involved in education system. 


\section{References}

Abuarqub, M. (2009). Islamic perspectives on education. United Kingdom: Islamic Relief Worldwide Publisher.

Ahamd, A. (2017). Causes of low literacy in Pakistan. Asian Journal of Social Science, $5(3), 44-54$

Amir, M. (2019). Factors influencing girls' education in Pakistan. Online Journal of Social Science, 4(3), 54-65.

Chaudhry, I. S., Malik, S., \& Ashraf, M. (2006). Rural poverty in Pakistan: some related concepts, issues and empirical analysis. Pakistan Economic and Social Review, 259-276.

Creswell, J. W., Plano Clark, V. L., Gutmann, M. L., \& Hanson, W. E. (2003). Advanced Mixed Methods Research Designs. In A. Tashakkori, \& C. Teddlie (Eds.), Handbook of Mixed Methods in Social and Behavioral Research (pp. 209-240). Thousand Oaks, CA: Sage.

Din, M. N. U., Dad, H., Iqbal, J., Shah, S. S. A., \&Niazi, M. I. (2011). Causes of male dropout rate in Pakistan. Journal of College Teaching E Learning (TLC), 8(4), 37-42.

Durrani, A. S. (2016). Why does Pakistan have a low literacy rate? International Journal of Education, 7(3), 45-55.

Ejaz, A., Afzal, M. Y., \&Shurgeel, H. K. (2015). A review of rural women education in Pakistan. Science International (Lahore), 27(1), 555-559.

Hussain, A., \& Salfi, N. A. (2011). Causes of Low Literacy Rate in Pakistan: A Survey Based Study. International Journal of the Book, 8(1).

Javaid, H. (2017).Education In Pakistan, A White Paper; Document to Debate and Finalize the National Education Policy. Ministry of Education Pakistan

Kim, B.-S., Lee, D.-W., Bae, J. N., Chang, S. M., Kim, S., Kim, K. W., \& Cho, M. J. (2014). Impact of illiteracy on depression symptomatology in communitydwelling older adults. International psychogeriatrics, 26(10), 16-29.

Miraj, M.H (2013, September 16). The Kot of Kamalia, DAWN, https://www.dawn.com/news/1043306.

Mtiaz, E.H. (2020, August 04) 'Literacy rate', The Nation, https://nation.com.pk/04Aug-2020/literacy-rate.

Naeem, S. (2013). Causes of Low Literacy Rate in Pakistan. Scribed, 27. 
Nauman, A. K. (2020). Illiteracy in Pakistan. Pakistan Review of Social Sciences, Vol. 1, No. 2, 60-73

Pakistan Bureau of Statistics (2017). District and Tehsil level population summary with region breakup. Pakistan Bureau of Statistics. http://www.pbscensus.gov.pk/sites/default/files/bwpsr/punjab/TOBA\%20T EK\%20SINGH_SUMMARY.pdf

Pakistan Bureau of Statistics (2021). District And Tehsil Level Population Summary With Region Breakup, Available at: https://www.pbs.gov.pk/sites/default/files/bwpsr/punjab/ TOBA\%20TEK\%20SINGH_SUMMARY.pdf

Quora. (2015). What is the relationship between literacy and religion in Islam? https:/ / www.quora.com/What-is-the-relationship-between-literacy-andreligion-in-Islam.

Qureshi, S. (2003). Pakistan: Education and gender policy girl's education: A lifeline to development. Budapest: Center for Policy Studies, Central European University.

Saqib, M., \& Ahmad, S. M. (2014). Root causes of low female literacy in FATA Pakistan :( a case study of Jalozai camp). International Journal of Academic Research in Business and Social Sciences, 4(3), 45-57.

Tahira, A. (2018). Impact of low literacy on societies. Journal of social and behaviorural science 4(1), 55-63

Thengal, N. (2013). Social and Economic Consequences of Illiteracy. Journal of Teaching E Learning, 8(4), 37-43.

Victoria. (2019). Illiteracy: Meaning, Causes, Effects, Consequences and Solutions. Imp center. 